International Journal of Agriculture, Environment and Bioresearch

Vol. 4, No. 03; 2019

ISSN: $2456-8643$

\title{
SPATIAL DISTRIBUTION OF INSALUBRITY WITHIN THE CITY OF COTONOU
}

\author{
HOUNKPONOU N. Edouard Prince ${ }^{1}$, AZONHE S. H. Thierry ${ }^{2}$, AGBOSSOU K. Euloge ${ }^{3}$ \\ ${ }^{1}$ Department of geography and land Planning, Abomey - Calavi university, 01BP : 526 Cotonou 01 \\ ${ }^{2}$ Benin Center for Scientific Research and Innovation (CBRSI) \\ ${ }^{3}$ Laboratory of Hydraulics and Water Control (LHME)/ Faculty of Agronomic Sciences/ University of Abomey - \\ Calavi \\ http://doi.org/10.35410/IJAEB.2019.5368
}

\begin{abstract}
The fundamental objective of this research is to provide a better understanding of what causes insalubrity within the city of Cotonou.

The probabilist method and the random choice technique have been used in the selection of the sample proportionally to the size of the structures based on some criteria. The sample's size is determined in accordance with Schwartz method. In order to identify the causes of insalubrity, the parameters were introduced in the mini tab software to perform the simple regression analysis. The Durbin-Watson's statistic, Ryan Joyner normality and Henri adjustment were used to assess the significance of the model. The evaluation study of healthy places is conducted through factors such as : rain water evacuation network, flood and coverage rate of pre-collection in order to determine a healh card. The combination of the factors of safety of the spaces is realized. It was calculated, the insalubrity rate (IS1) taking into account the effects of anthropogenic factors (rain water evacuation network coverage rate of pre-collection and volume of waste) on the salubrity.

The regression analysis reveals that the increase of suscription fees by pre collection structures, the availability of empty spaces in urban districts, the setting up of waste gathering points in towns justify the rise of insalubrity rate in the urban areas studied. Moreover, an increase in the frequency of household solid waste collection (MSW) in households, reduces the suscription rate and compels households to discharge solid wastes in empty spaces in their neighborhoods or refer to the gathering points that are poorly maintained and rarely emptied
\end{abstract}

Keywords: Insalubrity, waste, management, Cotonou, Benin.

\section{INTRODUCTION}

The issue of insalubrity is more and more addressed by many environmental policies in the cities of developing countries. The Rio Conference in 1992, showed particular interest in the management of the urban environment with the issue of salubrity as a priority for the sustainable development of southern towns (Dorier-Apprill, 2002). This major concern has resulted in a flurry of seminars, conferences, symposiums and official publications on the city cleanliness at both local and global levels. The problematic of cleanliness is becoming the preoccupation of number of international organisations chiefly, the United Nations, the World Bank and 
developed countries governments (Coopérations bilatérales) (Sy, 2006). The rise of interests about the issue shows its importance at both local and global levels : these interests are sanitary, environmental, social, economic and politic, etc.

The rapid urbanization prevailing in African cities, stresses the insalubrty issues. Faced with the inability to control urban dynamics and meet the massive social demand due to the gradual failure of state supervision systems, African cities pose daunting in managing services that affect water, sanitation, garbage collection, transportation, housing, education, lighting, access to health care, etc. The limited means of African governments hamper their effective management of sanitation issues (Sy, 2006). Thus, urban spatial development in a context of under-equipment and almost universal poverty of the majority of the urban layers is accompanied by a set of urban mutations whose deficiencies in the field of salubrity are one of the multiple manifestations. In addition, urban spaces themselves are strongly differentiated. The colonial era differences are not completely obliterated, but the deterioration of buildings and networks tends to blur them when new investments have not taken place (Piermay, 2004).

An overview of salubrity issues in African cities helped to appreciate the difficulties of urban management. With the political, social, economic, technical, environmental and health changes that are affecting it, the issue of sanitation is putting a strain on urban management. Indeed, the salubrity management is only a component (although essential) of a larger field of urban management. According to Jaglin and Dubresson (1999), urban management brings together two fields of intervention: on the one hand, "all the processes of coordination and regulation that contribute to the functioning of the city"; on the other hand, "all acts of a political nature aimed at the conciliation of competing claims and interests which cannot be equally satisfied". The salubrity management therefore interferes with all urban management and with all social and political practices. However, it cannot be completely isolated from other services in urban management (Piermay, 2004). The links are very strong, between municipal and family budgets, which must constantly make arbitrations. But the links are also logical between the different services of urban management.

\subsection{Study environment}

The city of Cotonou is situated between parallels $6^{\circ} 21$ and $6^{\circ} 24$ north latitude and between $2^{\circ}$ 22 and $2^{\circ} 30$ east longitude. It is bounded on the north by Nokoué lake, on the south by the Atlantic Ocean, on the west by the communes of Ouidah and Abomey-Calavi, and on the east by the municipality of Sèmè-Podji (Figure 1). . It covers an area of $79 \mathrm{~km} 2$. It comprises $35 \%$ of marshy areas and $65 \%$ of urbanized areas on both sides of the channel. 


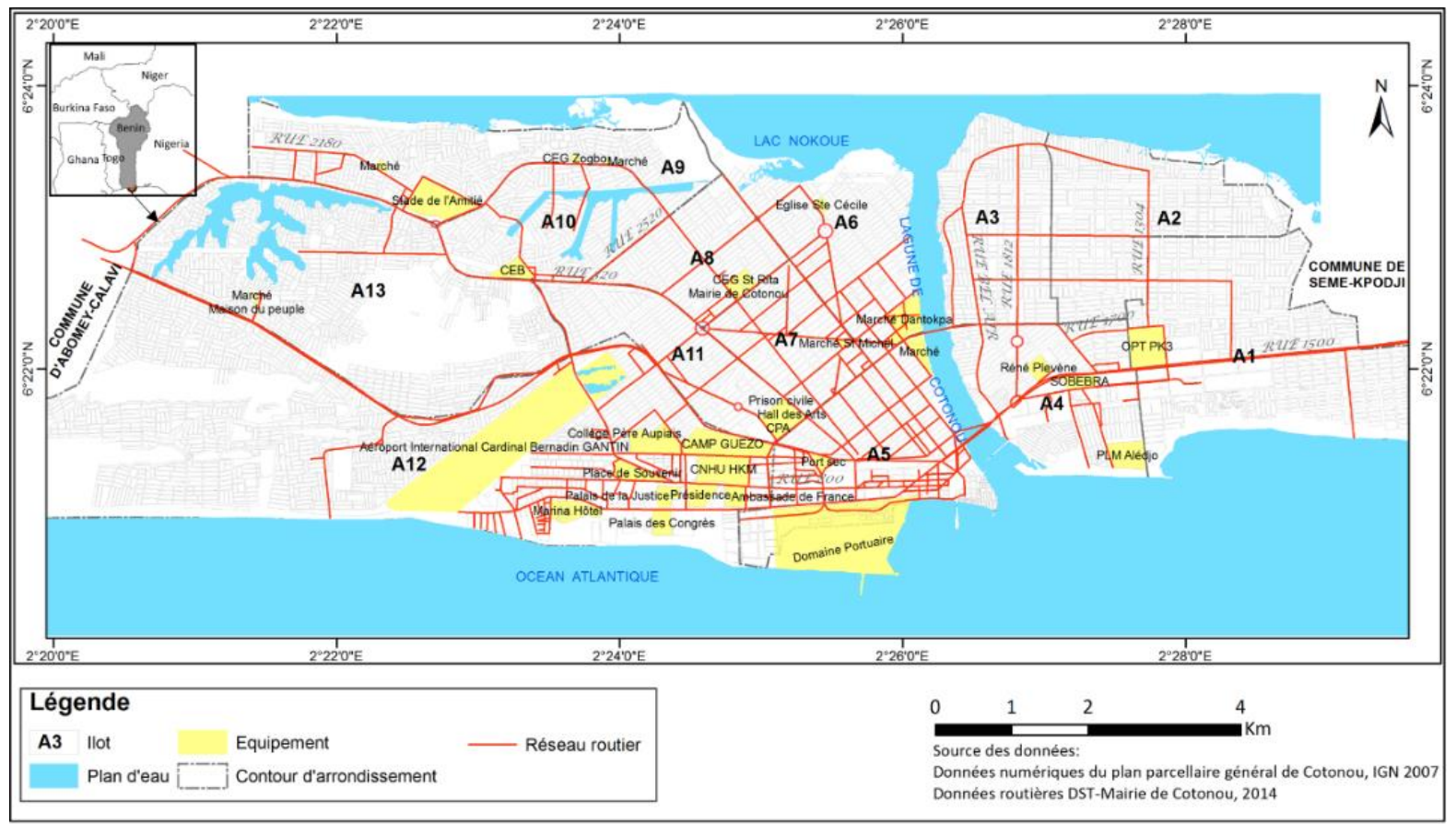

\section{DATA AND METHODS}

\section{Collected Data}

The collected data are qualitative. They relate to :

$>\quad$ Waste management structures: data on the number of subscribers, the quantity of DSM pre collected daily, the number of carters, the work tools, the coverage rate. They are collected from COGEDA;

$>$ Solid waste data: the information collected relates to the management of solid household waste and the quantity of daily production of DSM in the city of Cotonou. They are collected from households, managers of pre-collection structures and local elected officials and PUGEMU;

$>\quad$ Waste collection points and their spatial distribution: they concern the different points of grouping of household waste in the study environment. They are collected from the heads of pre-collection structures;

$>\quad$ Local solid waste management strategies; they relate to householdsmeans of waste management. They are collected from households;

$>\quad$ The steps of the household solid waste management process; they show the different steps of household waste management. They are collected from different reports and

Figure 1 : Geographical situation of Cotonou ................................... neir number in the communes, their spatial distribution, the number of workers exploited, the quantity of DSM pre-collected daily, 
the working tools and the rate of blanket; These data are collected from pre-collection structures and DST.

\section{Methods}

The processing of the data began with a rigorous analysis based on the spatialization of the information collected. The sheets are checked, coded and then scanned using Microsoft Excel software. The data entered was imported into various statistical packages namely SPSS 21.0, Xlstat Pro 7 and STATA 11 for their processing. The descriptive statistics are realized. To identify the determinants of insalubrity, the parameters were introduced in the mini tab 14 software to perform the simple regression analysis. Durbin-Watson statistic, Ryan Joyner normality, and Henri adjustment tests were used to assess the significance of the model.

The evaluation study of safe spaces is carried out through four factors (rainwater evacuation network, flood, pre-collection coverage rate and volume of waste) in order to determine a map of salubrity. For this purpose, we have defined, for each factor, classes coded in ways that reflect the influence of each in the estimation of the healthiness.

Table I: Classification of evaluation factors for safe spaces

\begin{tabular}{|lllc|}
\hline Factor & Salubrity factors & Class of salubrity & Code \\
\hline \multirow{2}{*}{$\begin{array}{l}\text { Rain water evacuation } \\
\text { network }\end{array}$} & Does not exist & Low & 1 \\
& Exists and degraded & Average & 2 \\
& Exists & High & 3 \\
\cline { 2 - 4 } Precollect Coverage & $31-45 \%$ & Low & 4 \\
& $46 \%$ and over & High & 5 \\
\cline { 2 - 4 } & Less than $500 \mathrm{~m}^{3}$ & Low & 6 \\
\hline \multirow{3}{*}{ Waste Volume } & $500 \mathrm{~m}^{3}$ to $1500 \mathrm{~m}^{3}$ & Average & 7 \\
& More than $1500 \mathrm{~m}^{3}$ & High & 8 \\
\cline { 2 - 4 } & No flood & Low & 10 \\
\hline Flood & Temporary flood & Average & 20 \\
& Permanent flood & High & 30 \\
\hline
\end{tabular}

The space salubrity factors combination is carried out in two stages to take into account the particular effect of flooding and makes rain water evacuation systems an important element. 
We calculate for this purpose a first insalubrity index (IS1) taking into account the effects of the three anthropogenic factors (rainwater drainage network, pre-collection coverage rate and the volume of waste) on salubrity by the formula :

$\boldsymbol{I} \boldsymbol{S}_{\mathbf{1}}=\sum \sum \boldsymbol{p}_{\boldsymbol{i}} * \boldsymbol{f}_{\boldsymbol{i j}}$

In this formula:

$\boldsymbol{p i}$ represents the weighting of parameter (i), with $\mathrm{i}$ varying from 1 to 3 (rainwater drainage network, pre-collection coverage rate and the distribution of wild dump sites)

- $\quad \boldsymbol{f} \boldsymbol{i} \boldsymbol{j}$ is the implication of class (j) for the factor $\mathrm{f} i$.

Weighting values $\boldsymbol{p} \boldsymbol{i}$ can influence the salubrity level choices. To fix these values, we were inspired by the knowledge of the field. The highest weighting is attributed to the "Rain water evacuation network" factor, which is considered the dominant factor and the lowest the volume of waste by sector. Table II shows the factor weighting values extracted from the logical tree.

Table II:Factor weights and classes contributions

\begin{tabular}{|c|c|c|c|c|c|}
\hline \multicolumn{6}{|c|}{ Factors } \\
\hline \multicolumn{2}{|c|}{$\begin{array}{c}\text { Rain water evacuation } \\
\text { network }\end{array}$} & \multicolumn{2}{|c|}{$\begin{array}{l}\text { Rates of coverage } \\
\text { precollection }\end{array}$} & \multicolumn{2}{|c|}{ Waste Volume } \\
\hline \multicolumn{2}{|c|}{ weight 3} & \multicolumn{2}{|c|}{ Weight 2} & \multicolumn{2}{|c|}{ weight 1} \\
\hline Class & Contribution & Class & Contribution & Class & Contribution \\
\hline Low & 3 & Low & 1 & Low & 1 \\
\hline Average & 2 & Average & 2 & Average & 2 \\
\hline High & 1 & High & 3 & High & 3 \\
\hline
\end{tabular}

We then calculate the unsanitary index for each space (j) IVS $\mathrm{j}$ by the formula:

$I S_{j}=p_{j * I S_{1}}$

In this formula, $\boldsymbol{p}_{\boldsymbol{j}}$ represents the weighting of the flood factor.

\section{Findings}

2.1 Spatial analysis of the effect of drainage networks on unhealthy conditions in the city of Cotonou

In the city of Cotonou, there are two types of collectors. Primary and secondary collectors. The primary collectors are oriented towards the Cotonou lagoon (natural outlets) while the secondary collectors cross the whole city of Cotonou, Hounkponou (2014). The secondary collectors cover a total length of $243909 \mathrm{ml}$ including $182814 \mathrm{ml}$ for the covered and open secondary collectors; then $61,095 \mathrm{ml}$ for the buried secondary collectors. But, Gnèlé, 2010 finds that the city of Cotonou has in 2008, 350,538 $\mathrm{ml}$ of collectors including 45,000 $\mathrm{ml}$ of primary and 305,538 $\mathrm{ml}$ of secondary. These works come to show that work of realization of the collectors evolved in the 
time. The city of Cotonou, despite having all these rainwater drainage infrastructures, is faced with periodic floods creating unsanitary conditions in the city. Figure 2 shows the different spaces channeled in the city of Cotonou.

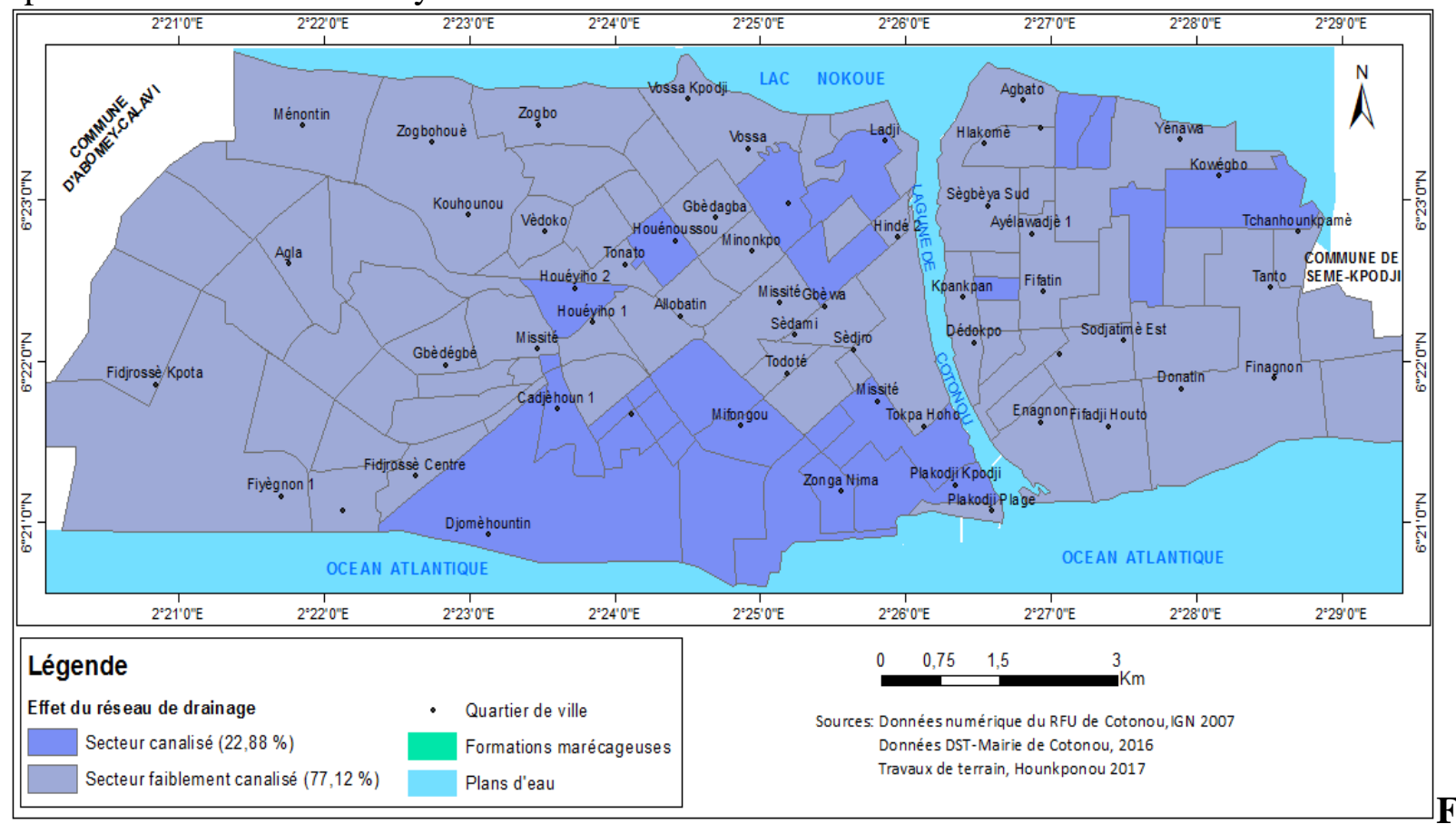

gure 2 :Effect of the drainage network on insalubrity in the city of Cotonou

Figure 2 shows that the southeastern and northeastern parts of the city of Cotonou are very salubrious. This can be explained by remediation work that is concentrated in these areas. These salubrious spaces occupy about $22.88 \%$ of the total area of the city of Cotonou against $20.36 \%$ in Porto-Novo. The city of Cotonou seems to be more drained (350,538 linear meters) than that of Porto-Novo (60,000 linear meters). However, the insalubrity of more than $77 \%$ of the Cotonou area is linked to the fact that these areas are not drained. In fact, the absence or inefficiency of drainage infrastructure accentuates the unhealthiness of certain parts of Cotonou, especially after the rains. Solid waste disposed of as a dump, drowns in rainwater due to lack of drainage of these waters to the outlet. This mixture of water and waste creates an unhealthy environment, especially during rainy periods.

For example, in the city of Cotonou, collectors are often clogged with waste. (Photos 1 and 2). 


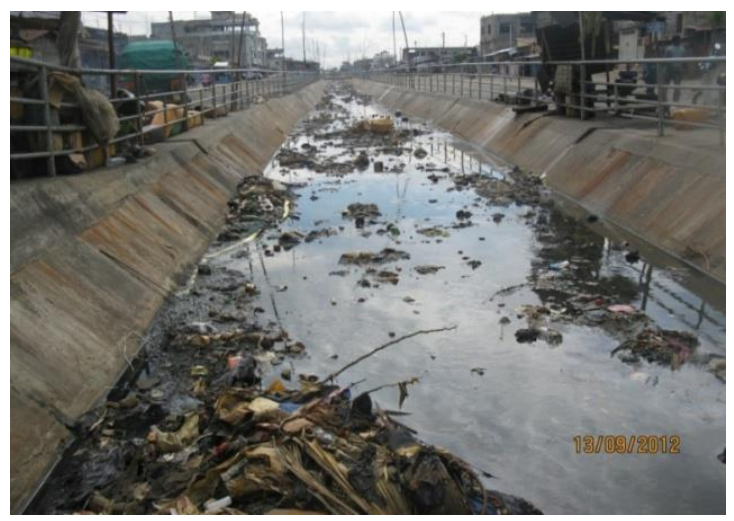

Photo 1 : Open gutter obstructed by DSM at Agbato

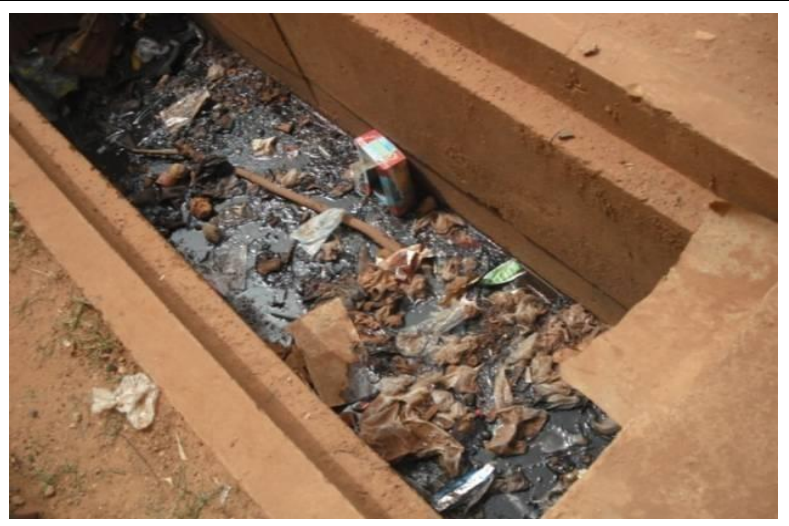

Photo 2 : Waste in primary gutters in Jericho

The DSM (Household Solid Waste) presence in gutters is due to the populations anti - social behaviours. These attitudes contribute to the obstruction of the gutters, prevent the flow of rainwater and wastewater thus increasing the risk of flooding.

\subsection{Spatial Analysis of the Effect of Household Solid Waste on Insalubrity in the Town of Cotonou}

Household solid wastes in an environment are sources of insalubrity. The figure 3 shows the impact of Household Solid Waste on the natural environment of the city of Cotonou.

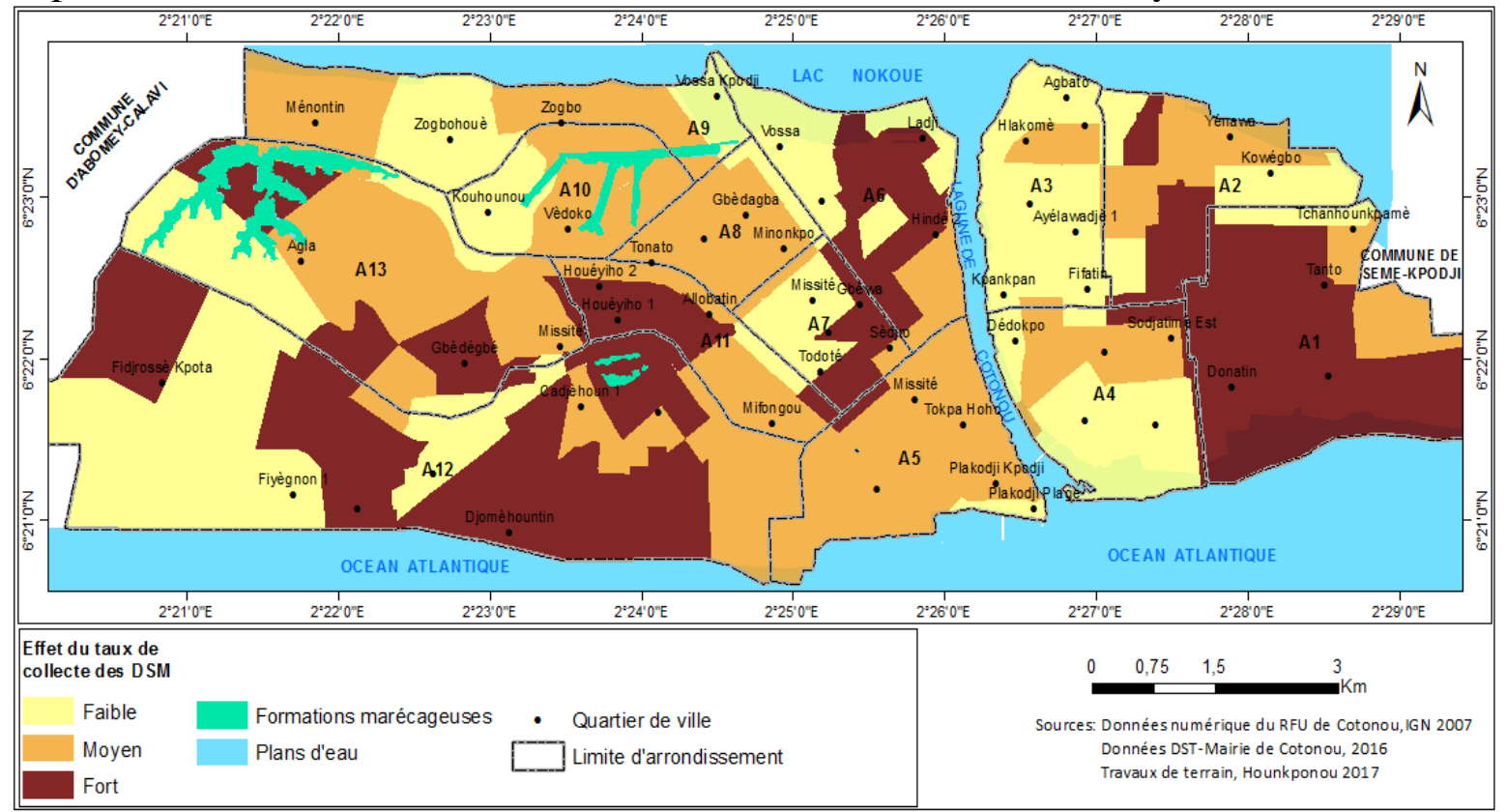

Figure 3: Household solid wastes impact on insalubrity in Cotonou

The Figure 3 shows a low collection rate in the city of Cotonou.But this situation is more accentuated in the 3rd, 4th 5th, 8th, 9th and 10th districts of the city. Also, it should be noted that the areas with low collection rates are located along the Cotonou Lagoon and Lake Nokoué. This can be explained by the proximity of the houses to the lagoon and the lake. This same observation is made by Fiogbé, (2015) who thinks that almost all the streets of Cotonou are 
littered with rubbish. Around the lagoon and, the swamps are erected in wild dumps, privileged places of defecation and rejections of all waste.

Households prefer to discard solid waste in the lowlands than to subscribe. For example, we can identify in the figure 3 the districts like Hindé, Ladji, Vossa in the 6th district, Agbato, Hlacomè, Kpankpan in the 3rd, Dédokpo in the 4th, Missité, Tokpahoho, Placodji beach and Placodjikpodji in the 5th district which border the lagoon of Cotonou and whose households engage in these practices. In the 9th district, the collection rate is very low also in Zogbohouè in Mènontin and Zogbo. These neighborhoods line Lake Nokoué.

\subsection{Spatial analysis of the effect of floods on insalubrity in the city of Cotonou}

Floods are decisive in the hygiene of the living environment. Given city of Cotonou is regularly vulnerable to extreme rainfall, the figure 4 shows the impact of floods on insalubrity in the city.

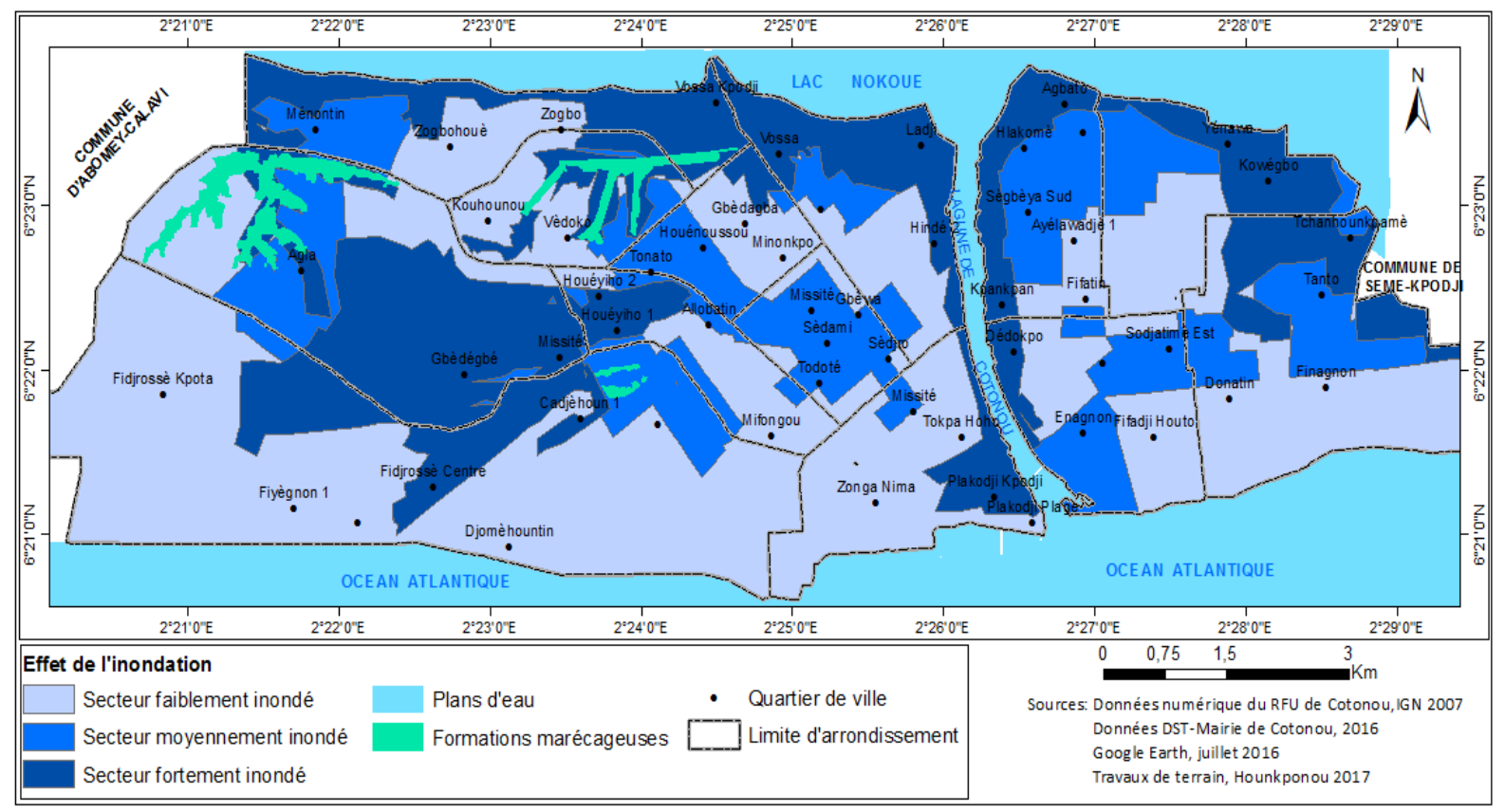

Figure4 : Flood impact on insalubrity in the city of Cotonou

The analysis of the figure 4, shows two cases about the effect of flood on insalubrity. The weakly affected areas and medium and high impact areas.In fact, the weakly affected sectors are spread over the whole city. They are found basically in the center, south, east and west of the city of Cotonou. This is due to the channeling policy developed in these areas. Figure 4 shows a good concentration of primary collectors in the center to the south and east of the city. The presence of these infrastructures contributes to the channeling of rainwater to natural outlets. These areas occupy about $51.18 \%$ of the total area of the city of Cotonou. They are characterized by an average subscription rate that oscillates between $20 \%$ and $30 \%$. The observation made it possible to notice that there are very few dumps whose surfaces vary between $2 \mathrm{~m} 2$ and 4,25 $\mathrm{m} 2$ with heights between 0.6 and $1 \mathrm{~m}$ in these sectors.

On the other hand, in areas that are moderately or very unhygienically flooded, there are more than 300 dumps with areas between $25.8 \mathrm{~m} 2$ and $4943.7 \mathrm{~m}^{2}$ with heights between 2 and 12 
meters. These dumps are recurrent along Lake Nokoué and the Cotonou Lagoon. It should be noted that in the 13th, 12th and 11th arrondissements, more precisely in districts like Agla, Missité, Gbèdégbé, Fidrousse, Vossa, Ladji, Fifadji, Zogbo and houéyiho, the effect of floods on insalubrity is more noticeable. This is justified by the non-subscription of households (12\%), the inefficiency of the pre-collection structures which mainly use antiquated tools with unskilled workers. The dissatisfaction of the households with the services of the structures of precollection leads them to break the contract and to throw the waste themselves anything which hinders the salubrity of their environment.

\subsection{Spatial analysis of insalubrity in the city of Cotonou}

The city of Cotonou is very dirty. This insalubrity spread over the whole city. It stands out especially along Lake Nokoué and the Lagoon of Porto-Novo. The figure 5 shows the level of insalubrity in the city of Cotonou.

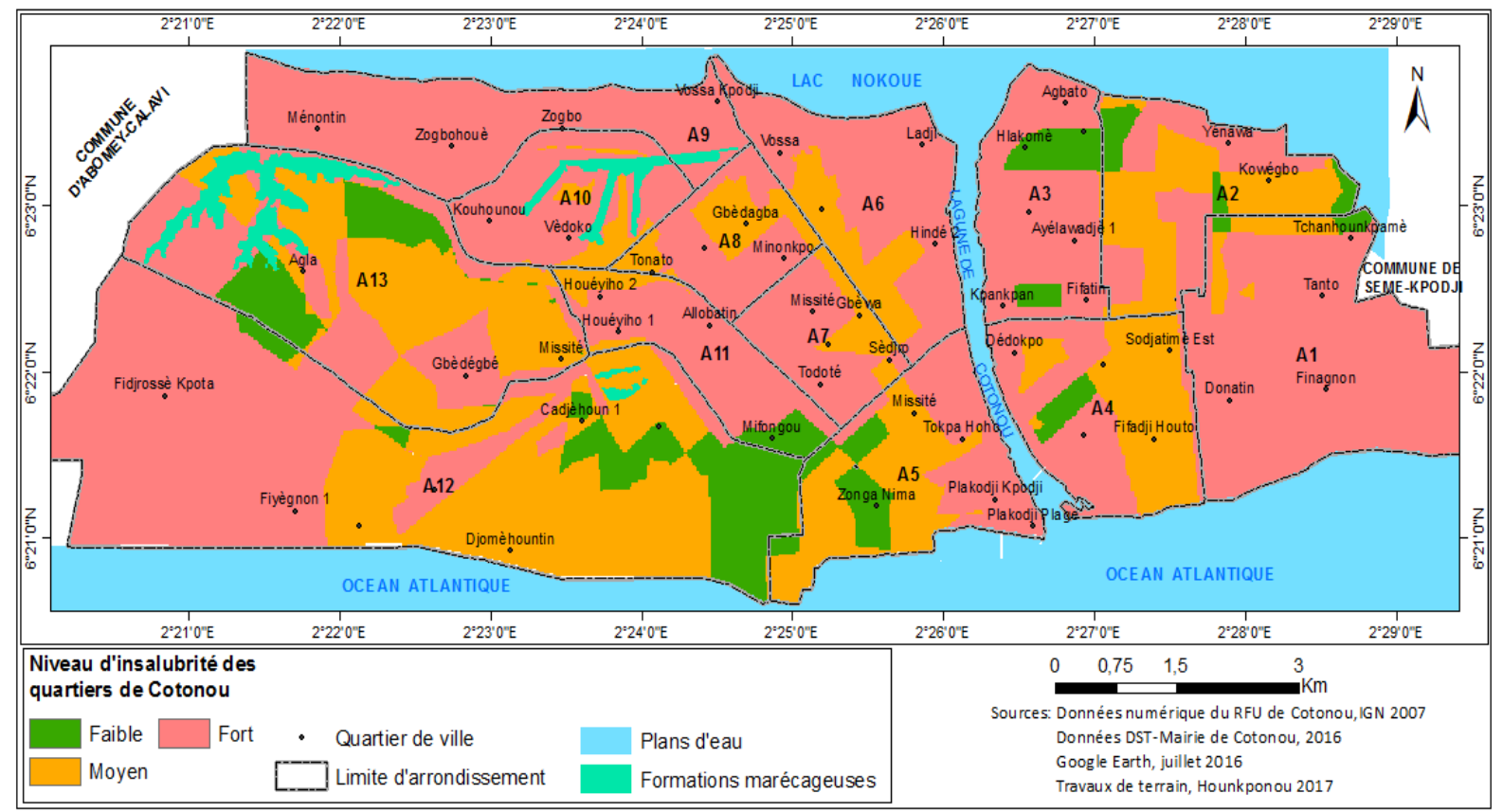

Figure 5 : The insalubrity level in neighborhoods in Cotonou

The analysis in Figure 5 shows that more than half of the city of Cotonou is dirty. In fact, $81.87 \%$ of the city's surface is dirty. This insalubrity is observed not only inside the city but especially along the Cotonou Lagoon and Lake Nokoué. This insalubrity is fundamentally linked to the waste released into the environment of the city. In Cotonou, the pre-collection activity is the fundamental step of the management system put in place. The insalubrity observed in the city is certainly linked to the limits of pre-collection. The Table III summarizes by sector the characteristics of pre-collection structures and those of dumpsites available. 
Vol. 4, No. 03; 2019

ISSN: $2456-8643$

Table III: Pre-collection structures and unsanitary in Cotonou

\begin{tabular}{|c|c|c|c|c|c|c|c|c|}
\hline & \multicolumn{3}{|c|}{ Characteristics of NGO/SMB } & \multirow{2}{*}{$\begin{array}{l}\text { Nber of } \\
\text { garbage } \\
\text { cans }\end{array}$} & \multirow{2}{*}{$\begin{array}{l}\text { Nber } \\
\text { of PR }\end{array}$} & \multirow{2}{*}{$\begin{array}{l}\text { Total nber } \\
\text { of } \\
\text { dumpspoi } \\
\text { nt }\end{array}$} & \multirow{2}{*}{$\begin{array}{l}\text { Average } \\
\text { areas of } \\
\text { dumpspoints }\end{array}$} & \multirow{2}{*}{$\begin{array}{l}\text { Height of } \\
\text { the } \\
\text { dumpspoint } \\
\mathrm{s}\end{array}$} \\
\hline & $\begin{array}{l}\text { Nber of } \\
\mathrm{NGO} / \mathrm{S} \\
\mathrm{MB}\end{array}$ & $\begin{array}{l}\text { Total Nber } \\
\text { of carts }\end{array}$ & $\begin{array}{l}\text { Number } \\
\text { of } \\
\text { workers }\end{array}$ & & & & & \\
\hline $\begin{array}{l}\text { Slightly } \\
\text { dirty } \\
\text { sectors }\end{array}$ & 8 & 26 & 48 & 08 & 02 & 15 & $\begin{array}{l}2 \mathrm{~m}^{2} \text { et } 4,25 \\
\mathrm{~m}^{2}\end{array}$ & $0,1 a ̀ 1 \mathrm{~m}$ \\
\hline $\begin{array}{l}\text { Moderately } \\
\text { dirty } \\
\text { sectors }\end{array}$ & 34 & 62 & 122 & 04 & 03 & 67 & $\begin{array}{ll}3,6 \quad \mathrm{~m}^{2} \\
943,2 \quad \mathrm{~m}^{2}\end{array}$ & 1 à 3 m \\
\hline $\begin{array}{l}\text { Very dirty } \\
\text { sectors }\end{array}$ & 56 & 60 & 124 & 04 & 07 & 97 & $\begin{array}{l}6,8 \quad \mathrm{~m}^{2} \\
2943,7 \mathrm{~m}^{2}\end{array}$ & $3 \mathrm{~m}$ à $8 \mathrm{~m}$ \\
\hline
\end{tabular}

The analysis in Table III shows that the pre-collection is organized by eight (08) NGOs / SMEs with twenty-six (26) carts and forty-eight (48) workers, while the moderately dirty sectors count, thirty-four (34). ) pre-collection structures, sixty-two (62) carts and one hundred and twenty-two workers (122) as against fifty-six NGOs / SMEs, sixty (60) carts and one hundred and twentyfour (124) workers in very dirty areas.

We note that very few structures intervene in slightly dirty neighborhoods. Contrariwise, structures are concentrated in dirty neighborhoods. The latter, deploy fewer workers in the field and have very few carts for service especially in highly insalubrious neighborhoods. This behavior can be justified not only by the lack of financial capacity of the structures to appropriate work tools but also by a lack of technical and financial support from the Cotonou City Council. This lack of equipment in certain pre-collection structures explains the poor service rendered to subscribing households who decide to break their contract and begin to benefit from the complicity of nature in managing the waste produced. Thus, they throw the waste into the environment of the city. These behaviors are part of the insalubrity observed in some districts of the city of Cotonou.Also, Table III allows us to understand that poorly insalubrious neighborhoods are sufficiently equipped with garbage bins (08) but fewer clustering points (02) than medium and highly unhealthy areas.In the city of Cotonou, slightly dirty neighborhoods benefit from a good organization of the pre-collection with a regular passage (3 turns / week) of the workers. The rate of recovery of subscription fees is close to $85 \%$, which contributes to the motivation of those responsible for pre-collection structures. While the highly insalubrious neighborhoods have more clustering points than other sectors, insalubrity persists. The real cause is that the regrouping points set up in the city of Cotonou are distant from the workers. They travel an average of three kilometers even more, just to dump pre-collected household solid waste. Worn out by fatigue after a few turns, $56.25 \%$ of these workers leave the remaining households by which they resume work the next day. During the fieldwork, $45.2 \%$ of the workers reported passing one per week and 52.3\% explain that they make two passages per week. We notice then that in the city of Cotonou, the pre-collection structures do not respect the clauses of contract. While some structures $(12 \%)$ strive to comply with contract clauses and regularly pick up household solid waste, more than $80 \%$ of these structures trivialize precollection. Failure to comply with the clauses causes some households to break the contract and 
resort to nature. In addition, the proximity of the garbage bins makes it easier for the workers. This explains above all the healthiness observed in certain districts of OHE, Camp Guézo, Port Autonome, Gbèdiga, Ste Jean, Cadjèhoun 2, Cocotier, Haie vive, Ahouanlèko, Cadjèhoun 1, etc. in Cotonou. In these localities $(85.6 \%)$ pre-collectors admitted that the proximity of garbage bins is a great asset in the pre-collection system. Indeed, they have no problem to go dump the household solid wastes in these bins. The proximity of these infrastructures contributes to the regularity of pre-collection, which means that there are very few dump sites.

In moderately substandard neighborhoods, field work made it possible to count sixty-seven (67) dumps with an area of $3.6 \mathrm{~m} 2$ to $943.2 \mathrm{~m}^{2}$ each with a height ranging from 0.6 to $2 \mathrm{~m}$, while in those It is estimated that one hundred and fifteen (115) dumps with an area of $6.8 \mathrm{~m} 2$ and 2943.7 $\mathrm{m}^{2}$ and a height of 3 to 8 meters can be counted. The large areas of dumps observed in the slums of the city of Cotonou, are located along the Cotonou Lagoon and Lake Nokoué. The presence of these dumps along the banks is linked to the rejection of household solid waste pre collected by some pre-collection agents. The proximity of clustering points may explain this behavior. The accumulation of waste along the banks justifies the heights as important observed.

Also, it should be noted that in poorly insalubrious neighborhoods, the government and the municipality of Cotonou have developed a sanitation policy. Indeed, the streets are well developed which facilitates not only access to subscribers but also to the collection points and garbage bins. In addition, these streets are also channeled to drain rainwater which influences the health of these neighborhoods. It shows a very important drainage system in all of these neighborhoods. Contrary wise, in unhealthy areas, the streets are sandy and littered with potholes. They retain water during the rain, thus creating obstacles to pre-harvest activity. Very few streets have been developed in these areas and the rainwater drainage system is lacking. The sanitation policy is discriminatory.

The lack of equipment for pre-collection structures, the poor distribution of collection points, the absence of garbage bins in the neighborhoods seriously affect pre-collection in some parts of Cotonou. These factors contribute to insalubrity in the city of Cotonou.

\subsection{Spatial distribution model of the rate of insalubity in the cities of Cotonou and Porto- Novo}

To identify the factors that contribute to the insalubrity of the neighborhoods in the cities of Cotonou and Porto-Novo, the linear regression analysis was carried out and its characteristics are as follows:

- Ryan Joyner and Henri adjustment test

- Fisher's test;

- Durbin-Watson statistic test.

Ryan Joyner's test and Henri's test make it possible to check if the conditions are right for the regression. Figure 6 illustrates the results from these tests. 

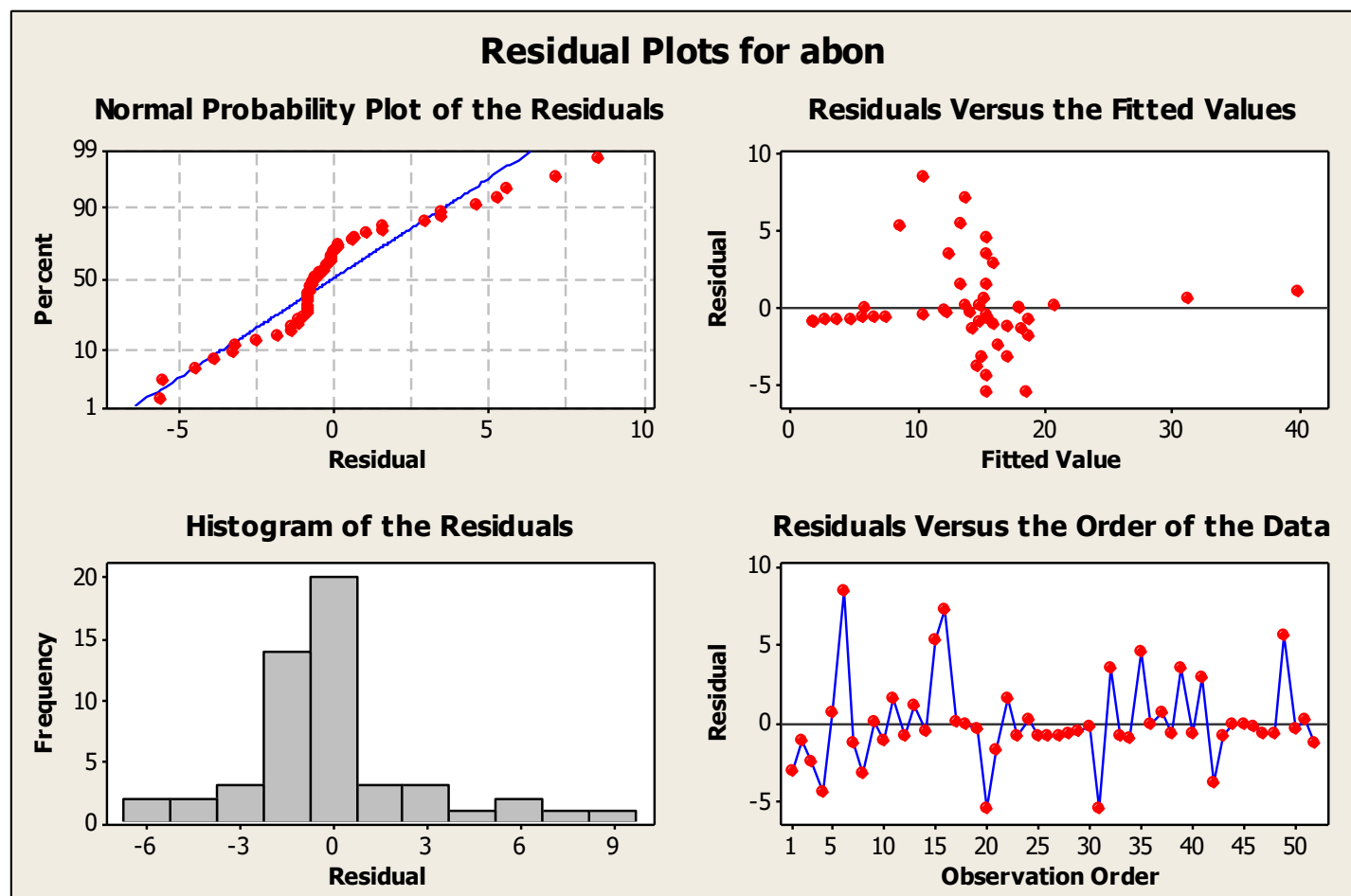

Figure 6: Henri's adjustment line of the regression

The figure 6 shows that all points are close to Henri's line. This justifies a perfect fit of the data. We can conclude from Ryan Joyner's normality tests and Henri's adjustment tests that the necessary conditions for regression are met.

The fisher test, of whichthe results are presented in Table IV, made it possible to judge the significance of the model.

Table IV: Fisher's Test on the Significance Analysis of the Amount of Information Provided by Variables in Regression

\begin{tabular}{|llllll|}
\hline Source & ddl & Sum of squares & $\begin{array}{l}\text { Medium } \\
\text { square }\end{array}$ & $\begin{array}{l}\text { F of } \\
\text { Ficher }\end{array}$ & $\begin{array}{l}\text { Prob } \\
\text { F }\end{array}$ \\
\hline $\begin{array}{l}\text { Model } \\
\text { residu }\end{array}$ & 4 & 2672,96 & 668,24 & 81,41 & $<0,000$ \\
\hline Total & 51 & 305,81 & 8,21 & & \\
\hline
\end{tabular}

The analysis in Table IV shows that the probability associated with the Fisher test is 0.0001 , ie less than $1 \%$ chance of being mistaken considering that the amount of information provided by the independent variables is significant for the model.

To evaluate the model, the Durbin-Watson test was used in this study, the results of which are shown in Table V.

Table V: Results of the coefficient of determination and Durbin-Watson statistic

\begin{tabular}{|ll|}
\hline $\mathrm{R}$ & 0,883 \\
\hline $\mathrm{R} 2$ & 0,874 \\
\hline
\end{tabular}


Vol. 4, No. 03; 2019

ISSN: $2456-8643$

\begin{tabular}{|lll|}
\hline R2 adjusted & 0,863 \\
\hline $\begin{array}{l}\text { Durbin-Watson } \\
\text { test }\end{array}$ & statistic & 1,92 \\
\hline
\end{tabular}

From the analysis in Table $\mathrm{V}$, the adjusted coefficient of determination $\mathrm{R} 2$ is 0.863 . This means that $86.3 \%$ of the variance is explained by the linear combination of the explanatory variables. The Durbin-Watson statistic test is 1.92 and is less than 3. Then the regression model is significant.

The model is written:

Insalubrity $=0.871+0.836$ cost -0.34 frequency +0.356 empty space $+0.547 \mathrm{PR}$

The insalubrity in neighborhoods is obtained by adding the subscription cost multiplied by 0.836 to the waste collection frequency multiplied by -0.34 , to the availability of empty space multiplied by 0.356 , to the presence of regrouping points multiplied by 0.547 .

Taking into account the parameters that explain the regression equation, the increase in the cost of subscription by pre-collection structures, the availability of empty space in neighborhoods, the installation of clustering points in agglomerations, increase the rate of insalubrity in the neighborhoods of the study environment.

\section{DISCUSSION}

\section{Determinants of insalubrity in the city of Cotonou}

The flood in Cotonou can be justified by the fact that its elevation ratings are generally low (4.5 $\mathrm{m}$ above sea level and more than $35 \%$ of the land is below $0.7 \mathrm{~m}$ ) and there is also an absence of true gradients that does not facilitate the drainage of rainwater. Also, the site of the city is dotted with several marshy areas, especially in neighborhoods like Vossa, Fifadji, Zogbo, Awansori, Avotrou, Agla, etc. This was also confirmed by Kouton, 2011. But, Okou, 1989 has a divergent view of the situation. For the former, the intensity of rainwater saturates the soil of the city that can no longer absorb the water. These then stagnate, sometimes for two to three weeks, causing material damage and completely obstructing certain traffic routes. But the latter thinks that in Cotonou, the soils are sandy and rest on a shallow water table. It can be noted that several factors are responsible for the frequency, persistence and permanence of the flood phenomenon in Cotonou. For example, natural environmental factors such as topography, soil type, hydrography and so on.

In Benin, the production of solid waste in 1998 was 342000 tons, of which $60 \%$ for the city of Cotonou OMS, (2010). In 2011, the city of Cotonou produced about 708 tons of household waste per day. Today this production is 3889.5 tons per day. However, according to officials of the DST of the municipality of Cotonou, the capacity of waste removal of the town hall does not exceed 100,000 tons per year. This creates a deficit of more than 40,000 tons in the collection. So, about 41,966.75 tons of DSM are squandered every year in the city. This situation is basically explained by the fact that very few households subscribe to pre-collection structures. This justifies the fact that Ousseynou (1996), N'Bessa (2001) estimated that the city of Cotonou is experiencing serious difficulties in the management of its waste. Policymakers do not think of reviewing the way in which waste is managed in the city despite the limitations of the system put in place. Today, wild dumps are erected here and there in the city with volumes ranging from 
$4000 \mathrm{~m} 3$ to $26000 \mathrm{~m} 3$ under the helpless gaze of municipal and government authorities blocking even times the flow of water. Soclo, (1999) and Gnèlé (2010) recognize that the presence of household solid waste in the city of Cotonou is due to the pre-collection system put in place. This proliferation of household solid waste, contributes to the insalubrity of the city. Regularity of pre-collection activity of household solid waste in households reduces the risk of unsanitary conditions in neighborhoods. When pre-collection structures are frequently used by subscribing households to collect the waste produced, the environment is healthy. On the other hand, the absence or the delay of pre-collection forces the households to free themselves from the household solid waste products. This is what explains the recourse to the nature. They dump the household solid waste produced in the empty spaces available in their environment or refer to the regrouping points. This behavior is denounced by several authors who carried out their studies in Cotonou and elsewhere. In Cotonou, Ganti's study reports (2011) show that people directly transport their garbage to the point of discharge (public skips, empty spaces). Also, Topanou (2012), in his study on the management of household solid waste in the city of Abomey-Calavi (Benin): Characterization and recovery trials by composting explains that the majority of the populations directly ensure the transport of their garbage in storing point (bush, public skips, empty spaces, at the edge of rails, at the edge of Inter-State tracks, along water bodies, public places, gutters).This observation is made by Yêmadjè, (2009) in his study on the basic sanitation problem: Case of the district of Abomey-Calavi. Moreover, Onibokun, (2002), in his study on "urban waste management, solutions for Africa", finds instead that rapid and unplanned urbanization is a factor in the deterioration of the environment through waste evacuation on illegal dumping sites. The latter could justify this behavior of the populations. On the other hand, the works of Yémadjè, (2009) and Topanou, (2012) could not show that the frequency of the DSM pre-collection activity, can remedy the rejection of waste on empty plots. They simply proved that the waste is thrown on empty spaces. The presence of empty spaces around dwellings in the neighborhoods of the city of Cotonou is therefore decisive for the insalubrity of these neighborhoods.Also, the regression has made it possible to note that the regrouping points are determining in the insalubrity of the neighborhoods which welcome them. Indeed, the household solid waste pre collected by the workers and deposited in the regrouping points stay long and sometimes overflow and then create further insalubrity in the immediate environment of these infrastructures. The collection structures that should regularly relieve congestion points are not tackling it. As a result, the waste passes stays in these infrastructures and becomes for the populations a threat by the smells that they release. Raoufou, (2015), in his study on the evaluation of the mechanism of solid and household waste treatment in the commune of PortoNovo finds that, the causes of insalubrity in Porto-Novo are numerous and varied and concern in particular the high population growth resulting in high production of waste from socio-economic activities, inefficient solid and household waste management services, ignorance, lack of awareness, etc. His study did not mention the mismanagement of the regrouping points whose consequences are the insalubrity observed around these infrastructures. Moreover, Hounwado, (2015) in a comparative study of the mode of solid waste management in the Hindé and Jak districts of Cotonou: approach for a sustainable management of houssehold solid waste has shown that the insalubrious is mainly due to a bad implication of the municipality and low NGO performance. The author, speaking of a bad implication of the Town Hall in the insalubrity of the city of Cotonou, seems to confirm our results. Indeed, the City Council must have the mission to 
control the other actors involved in the cleanliness of the city including the collection structures of the household solid waste. It must ensure that the collection points are regularly cleared of waste for the treatment sites. In the city of Cotonou, no specific study on insalubrity has identified clustering points as a determining factor in the insalubrity of the city.

Moreover, in the city of Cotonou, the increase of the subscription cost by the pre-collection structures reduces the subscription rate. The cost of the subscription in Cotonou is decisive in the cleanliness of the neighborhoods. Indeed, when the cost of the pre-collection subscription is affordable, the subscription rate is high. Meanwhile, the pre-collection structures in charge of picking up the household solidwaste are resolutely taking care of it and there are almost no dumps in the neighborhoods. On the other hand, when the cost of pre-collection is high, households whose income does not allow them to subscribe refer to nature to manage the household solid waste produced. In this case, there are several dumps in these environments which creates unsanitary conditions in neighborhoods. Hounguè, (2016) in his diagnostic study on the state of salubrity in Wlacodji showed that from 2014 to 2016 the number of subscriber increased gradually. For him, these results can be explained by the fact that the cost of the subscription is reduced to $500 \mathrm{f} \mathrm{CFA}$ in 2016 instead of $1000 \mathrm{f}$ and $1500 \mathrm{f} \mathrm{CFA} \mathrm{that} \mathrm{the}$ subscribers paid respectively in 2015 and in 2014. This study confirms in our results since it did not show the link between the subscription of households and the unsanitary of the neighborhoods.

\section{CONCLUSION}

Household solid waste management and unsanitary conditions are becoming more and more complex in Cotonou and Porto-Novo communes. This is linked not only to population growth, accompanied by an exaggerated increase in waste production but also, the increase in the cost of subscription by pre-collection structures, the availability of empty spaces in neighborhoods, installation of clustering points in agglomerations, increase the rate of insalubrity in the neighborhoods of the city of Cotonou.

The diversity of operators delegated forcleanliness services, the management practices are diverse and fragmented. As a result, discontinuous interventions create highly differentiated salubrity situations. So the organization in charge of the salubrity management has a deficit. What we know about urban responses that try to reduce the managerial deficit is that they eitheir reduce or accentuate intra-neighborhood disparities in Cotonou.It is therefore indisputable that, in many cities in sub-Saharan Africa, we are witnessing a proliferation of actors and a managerial fragmentation.A highly spatialized management of salubriity derives from this managerial fragmentation.A highly spatialized management of salubriity derives from this managerial fragmentation. At the city level, neighborhoods present diverse management dynamics: well-equipped and serviced neighborhoods, neighborhoods managed by community organizations, forgotten neighborhoods.

\section{REFERENCES}

DORIER-APPRILL, E., (2002) : Enjeux environnementaux et risques sanitaires dans la Ville (berges, bas-fonds et îles de Mopti) : des zones à risque, des espaces convoités. In EauEnvironnement-Santé, éditions ENSP, pp 221-235. 
FIOGBE, 2015 : Gestion des Déchets solides ménagers et Développement Durable dans le troisième arrondissement de la ville de Cotonou. Mémoire de Maitrise, 68P

GANTI T., 2011 : Gestion des ordures ménagères à Cotonou, rapport, 8 p.

GNELE J. E. (2010) : Dynamique de planification urbaine et perspectives de développement durable à Cotonou (RB). Thèse de doctorat unique de l'Université d'Abomey-Calavi, UAC, FLASH, $338 \mathrm{p}$.

HOUNGUE Oscar, (2016) : Etude diagnostique sur l'Etat de salubrité de Xwlacodji plage à Cotonou, Mémoire de fin de cycle, 63 pages, EPAC/UAC

HOUNKPONOU, (2014) : Activité de curage de caniveau et ses incidences sanitaires sur les employés de ce secteur d'activité dans la ville de Cotonou Mémoire de Master, 79P

HOUNWADO, (2015) : Etude comparative du mode de gestion des déchets solides ménagers dans les quartiers HINDE ET JAK de Cotonou : approche pour une gestion durable des DSM Mémoire de fin de cycle.46p

JAGLIN. S et DUBRESSON. A (1999) : Décentralisations et gouvernance urbaine en Afrique subsaharienne. La fragmentation est-elle inéluctable ? Communication à la $9^{\text {ème }}$ conférence générale de l'EADI 22-25 septembre 1999, 18p.

KOUTON A., (2011) : Changement climatique inondation dans la ville de Cotonou : diagnostic et analyse prospective. Mémoire de Maîtrise de géographie, soutenu à la FLASH/UAC. 70 p

N'BESSA B. (2001) : Cotonou et ses quartiers: Explication sur quelques noms dequartiers 17 p.

OKOU C. (1989) : L'urbanisation face aux systèmes naturels: le cas de Cotonou. Cahier d'Outre-Mer. XLII, 168, pp 425-438.

OMS, (2010) : Rapport sur le progrès en matière d'assainissement et d'alimentation en eau. Paris, France, 58 p.

ONIBOKUN A., 2002 : La Gestion des déchets urbains. Des solutions pour l'Afrique. Paris: CRDI, Karthala, ISBN: 0-88936-927-5, 260 p.

OUSSEYNOU E. (1996) : Problématique de la gestion des déchets solides en Afrique de l'Ouest et Centrale, série de séminaires PDM VIII, $170 \mathrm{p}$.

PIERMAY. J.L (2004) : La gestion des territoires de l'eau en Afrique sub-saharienne, entre mutation des espaces et mutation des sociétés. In séminaire de l'Institut Régional de Coopération Développement (IRCOD) sur la maitrise d'ouvrage et pratiques de gestion de l'eau, quelles orientations pour la coopération Nord-Sud, Strasbourg, 10-11 novembre, pp. 43-53.

RAOUFOU A. Koudous A. (2015): Evaluation du mécanisme de traitement des déchets solides ménagers dans la commune de Porto-Novo, Mémoire de fin de cycle, 56 pages, $\mathrm{EPAC} / \mathrm{UAC}$

SOCLO, H. (1999) : Inventaire et classification des sources majeures de pollution au Bénin, version préliminaire, $\mathrm{ABE}, 64 \mathrm{p} .+$ annexes.

SY, Z.E.A., (2006) : Géographie urbaine de l'insalubrité: le cas de Saint-Louis du Sénégal. Editions Harmattan, Paris, $200 \mathrm{p}$.

TOPANOU N., 2012 : Gestion des déchets solides ménagers dans la ville d'Abomey-Calavi (Bénin): Caractérisation et essais de valorisation par compostage. Thèse de Doctorat Université d'Abomey-Calavi, $194 \mathrm{p}$.

YEMADJE A., 2009 : Problématique d'assainissement de base : Cas de l'arrondissement d'Abomey-Calavi, mémoire de DEA, FLASH/UAC, 71 p. 